Original Article

\title{
REPRODUCTIVE POTENTIAL AND NESTING EFFECTS OF OSMIA RUFA (SYN. BICORNIS) FEMALE (HYMENOPTERA: MEGACHILIDAE)
}

\author{
Karol Giejdasz ${ }^{1 \star}$ \\ Monika Fliszkiewicz ${ }^{1}$ \\ Andrea Bednářová? \\ Natraj Krishnan ${ }^{3}$

\begin{abstract}
${ }^{1}$ Poznań University of Life Sciences, Poland
${ }^{2}$ Institute of Entomology, Biology Centre, Academy of Sciences Branišovská, the Czech Republic Department of Biochemistry, Molecular Biology, Entomology and Plant Pathology, Mississippi State University, USA

${ }^{3}$ Department of Biochemistry, Molecular Biology, Entomology and Plant Pathology, Mississippi State University, USA

*corresponding author: kagiede@up.poznan.pl

Received 21 September 2015; accepted 24 January 2016
\end{abstract}

A b s tract

The red mason bee Osmia rufa is a solitary bee belonging to the family Megachilidae, and is prone to nest in aggregations. Each female builds a nest separately in pre-existing cavities such as holes in wood and walls or empty plant stems. This is done by successively setting the cells in a linear series. In this study, we elucidate the nesting behavior and the reproductive potential of a single 0 . rufa female. The reproductive potential of nesting females was evaluated after the offspring finished development. We observed that an individual female may colonize up to five nest tubes and build 5-34 cells in them (16 on an average). During the nesting time the number of cells decreased with the sequence of nest tubes colonized by one female, which built a maximum of 11 cells in the first occupied nest and 5 cells in the last (fifth nest). Our observations indicated that $40 \%$ of nesting females colonized one nest tube as compared to $7 \%$ colonizing five nest tubes. Furthermore, in subsequent nest tubes the number of cells with freshly emerged females gradually decreased which was the reverse with males. Thus, the sex ratio (proportion of male and female offspring) may change during the nesting period. The female offspring predominated in the first two nesting tubes, while in the subsequent three tubes male offspring dominated. We also cataloged different causes of reduction in abundance of offspring in $O$. rufa females such as parasitization or problem associated with moulting.

Keywords: megachilidae, reproduction, nest, sex ratio, osmia rufa, offspring

\section{INTRODUCTION}

The red mason bee (Osmia rufa L., syn. $O$. bicornis) is a univoltine and polylectic bee species, common in Central Europe. This bee accepts diverse pre-existing cavities for nesting (Tasei, 1973). The nests architecture is typical for megachilid bees, which most commonly build linear nesting cells in dry, hollow stems or in wall cracks (Cane et al., 2007). A mixture of mud and secretions from the bees salivary glands are used for the division of the nest into cylindrical cells arranged linearly (Raw, 1972; Szentgyörgyi \& Woyciechowski, 2013). The cells аге supplied with pollen by the female on which it lays a fertilized (female-diploid progeny) or nonfertilized (male-haploid progeny) egg. Fertilized eggs are usually laid in the first cells that were built in the nest, while non-fertilized eggs are located closer to the nest entrance (Wilkaniec et al., 2000). The last cell built in the nest tube remains empty and protects the nest against parasites and abrupt changes of temperature inside the nest (Seidelmann, 1999).

The red mason bee is a solitary species which tends to nest in aggregations. The owner defends the nest against possible usurping females by pushing, striking or biting. These actions have 
been noted in megachilids in general, as territorial defensive strategies in the vicinity of a nest aggregation (Batra, 1978).

The great number of bees nesting in one location, stabilize the size of an aggregation. Extinction risk of small populations would be higher than that of large ones under conditions of weather fluctuations or negative habitat changes like limited food availability and the higher risk of parasitism (Ulbrich \& Seidelmann, 2001). The aggregation size of the next generation depends on such factors as: the number of nesting females in an aggregation, the number of cells built by each female, mortality during ontogenesis, or wintering seasons (Wójtowski et al., 1995).

The reproductive potential of an individual O. rufa female is not known. There are several studies which do provide information about the average number of nests or cells built by one female from the Osmia genus (Krombein, 1967; Vicens et al., 1993). In most studies, the number of cells inside the nest built by a single female, was calculated as a ratio of the number of cells in all nests and the number of nesting females (Bosh \& Vicens, 2005). So far, the effects exerted by the two factors mentioned above, were most often examined in relation to the nesting time divided into the beginning and the end of a nesting period (Torchio \& Tepedino, 1980; Bosh \& Vicens, 2005). Several studies also determined the developmental mortality, and number of bees reduced by parasites (Rosenheim, 1990; Goodell, 2003).

Scientific interest in $O$. rufa is not only academic but also has immense applied implications. The economic significance of this species as a crop pollinator cannot be underestimated (Schittenhelm et al., 1997; Fliszkiewicz et al., 2011). Osmia rufa has a strong preference for fruit trees and is an efficient pollinator in orchards (Krunic et al., 1995). This bee species is recommended for both field crop (e.g. rape) pollinating and crops in greenhouses (e.g. strawberry, high bush blueberry) (Wilkaniec \& Radajewska, 1996; Jauker et al., 2012; Rogers et al., 2013). As a pollinator, this bee species is more widely used by seed companies as well as plant growers, and as a model species by scientific institutions to study alternative pollinators (Kaminski, 2010). In Poland, $O$. rufa has become commercially available, and so it can be used as a managed pollinator from February until July. Strategies have been developed to manipulate the temperature conditions of keeping bees during the wintering period, and thus the wintering period can be shortened or prolonged. This manipulation allows for synchronising the bee emergence time with a particular crop's bloom period (Bosch \& Kemp, 2000, 2004; Sedivy \& Dorn, 2014). Despite the plethora of knowledge on the biology of $O$. rufa, not enough is known about the reproductive potential of the females. In the present study, we reported the number of cells built by one female and the number of the female's offspring, following an investigation of female activity during occupation of subsequent nest tubes. The results of our study may serve as a future starting point for analysis the influence of the female's age and the time of the nesting period on female fertility and the offspring sex ratio. Additionally, our results can also be used to assess the number of artificial nests in accordance with the number of nesting females in managed bee aggregations.

\section{MATERIAL AND METHODS}

\section{Experimental animals}

Osmia rufa bees were reared in artificial nests following the method of Wójtowski \& Wilkaniec (1978) where reed stalks (Phragmites australis) were used for the nest material. Identical $18 \mathrm{~cm}$ long nest tubes were used in the experiment during which bees were observed during the nesting period. There were 280 tubes with an inner diameter ranging from 6.5 to $8.0 \mathrm{~mm}$. The tubes were divided into four bundles and covered with a plastic cylinder. The artificial nests were set in the dendrology park of the Poznań University of Life Sciences, Poland, on $20^{\text {th }}$ April 2009. The analysed nesting period lasted from $3^{\text {rd }}$ May to $24^{\text {th }}$ June 2009.

At the beginning of the experiment, nesting females were caught, separated into plastic tubes and cooled in the refrigerator at $6^{\circ} \mathrm{C}$ for 
approximately 15 minutes. Following this, the bees used in the treatment were labeled by colored or numbered discs ( $2 \mathrm{~mm}$ in diameter). Shellac glue was used to stick the discs to the scutum of the thorax. This technique is commonly used for honey bee queen marking, and does not affect the bee's reproductive ability. For marking 0 . rufa females, a similar but smaller disc was used, which did not hinder the flying ability. In total, 29 females were labeled using this method, and these females were released around their nests.

The observations of the labeled females were conducted every day between 14:00 and 16:00 $h$, and were focused on the nest tubes supplied with pollen by the female. This time was sufficient to observe either the termination of the nest building or the starting of the building of another nest by the female. Newly occupied nest tubes were labeled with a pen marker until the nesting period was finished. Following this, the number of tubes settled by one female was determined and the nests were taken to the laboratory and kept at $22^{\circ} \mathrm{C}$ to complete all offspring development. From $20^{\text {th }}$ September, the nesting tubes with cocoons were stored outdoors. In February and March of the subsequent year (2010), the tubes with cocoons were cut open to determine the number of cells and cocoons as well as bees with developmental disorders or parasitic infections. The nest analysis also included the determination of nest cells with dead insects or totally empty cells.

Overall, 68 nests colonized by 29 labeled 0 . rufa females were analysed to determine the number of occupied nest tubes and number of cells built by one female. All nests were used to analyse the proportion of parasitised and empty cells. Only the nests with a minimum of two tubes settled, were used for determining the relationship between the sequence of occupied nest tubes and cell number or abundance of male and female offspring in particular nest tubes. There were 54 nests that were built by 17 females which belonged to this category. However, the proportion of male and female offspring (sex ratio) in the nests was determined based on the data obtained from the analysis of 32 nests built by 9 females. The reason was that it was only possible to identify the sex of the bees in those 32 nests. The nests, in which the developmental mortality was high, were excluded from the analysis.

\section{Statistical analysis}

Data were subjected to statistical analyses using the software packages Statistica (Statsoft, v. 9.0, Statsoft Inc., Tulsa, OK, USA) and JMP Pro (JMP', Version 11.0.0., SAS Institute Inc., Cary NC, USA, 1998-2012). To test for assumptions of normality and homoscedasticity - homogeneity of variances in the samples obtained, the Kolmogorov-Smirnov D test was used. Following this, a generalised linear model (GLM) regression analysis was used for testing the relationship between nest number and egg number or progeny number; and also between nest sequence and cell number or male/female number. A power analysis (Statistical Solutions, LLC) was also conducted to test sample-size effects when relationships by regression analysis alone were insufficient to draw conclusions. A one-way analysis of variance (ANOVA) with Tukey-Kramer post hoc tests was used for comparing means in different groups. Graphs were generated using GraphPad Prism 5.0 (San Diego, CA, USA) and columnar values are presented as mean \pm standard deviations.

\section{RESULTS}

Effect of number of nest tubes colonized on total cells constructed and offspring generated Osmia rufa females used from 1 to 5 tubes to build their nests ( $\bar{x}=2.6$ nests). More than half of the observed females (51.7\%, 15 individuals) used 2-4 nest tubes. About 41.4\% (12 individuals) of the observed bees used only one nest tube. Additionally, 20.7\%, 13.8\%, 17.2\%, and $6.9 \%$ of females used $2,3,4$, and 5 tubes, respectively. Generally, females in all nesting tubes built from 5 to 34 nesting cells (a compound average of 15.6 cells).

It was our observation that females colonizing only one nesting tube built substantially 

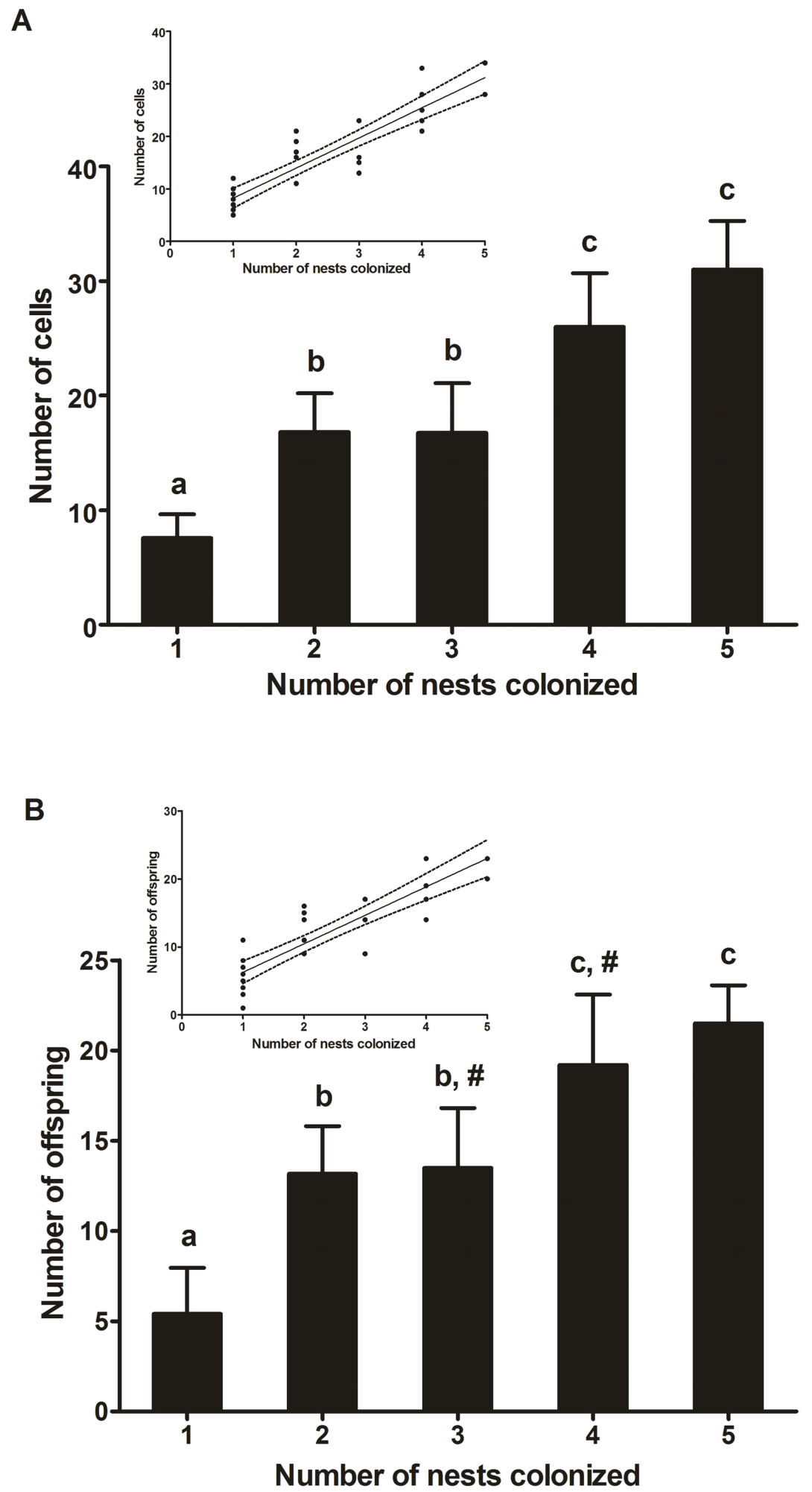

Fig. 1.

Relationship between the number of nests colonized by the $O$. rufa female, and the total number of generated cells (A) and offspring produced (B). Insets in (A) and (B) provide a regression line with scatter plot data. $95 \%$ confidence intervals are represented by dotted lines on either side of the regression line. Data for each bar are mean \pm SD of 29 individual females. Bars with different superscripts and/or symbols (\#) are significantly different at $p<0.001$ 

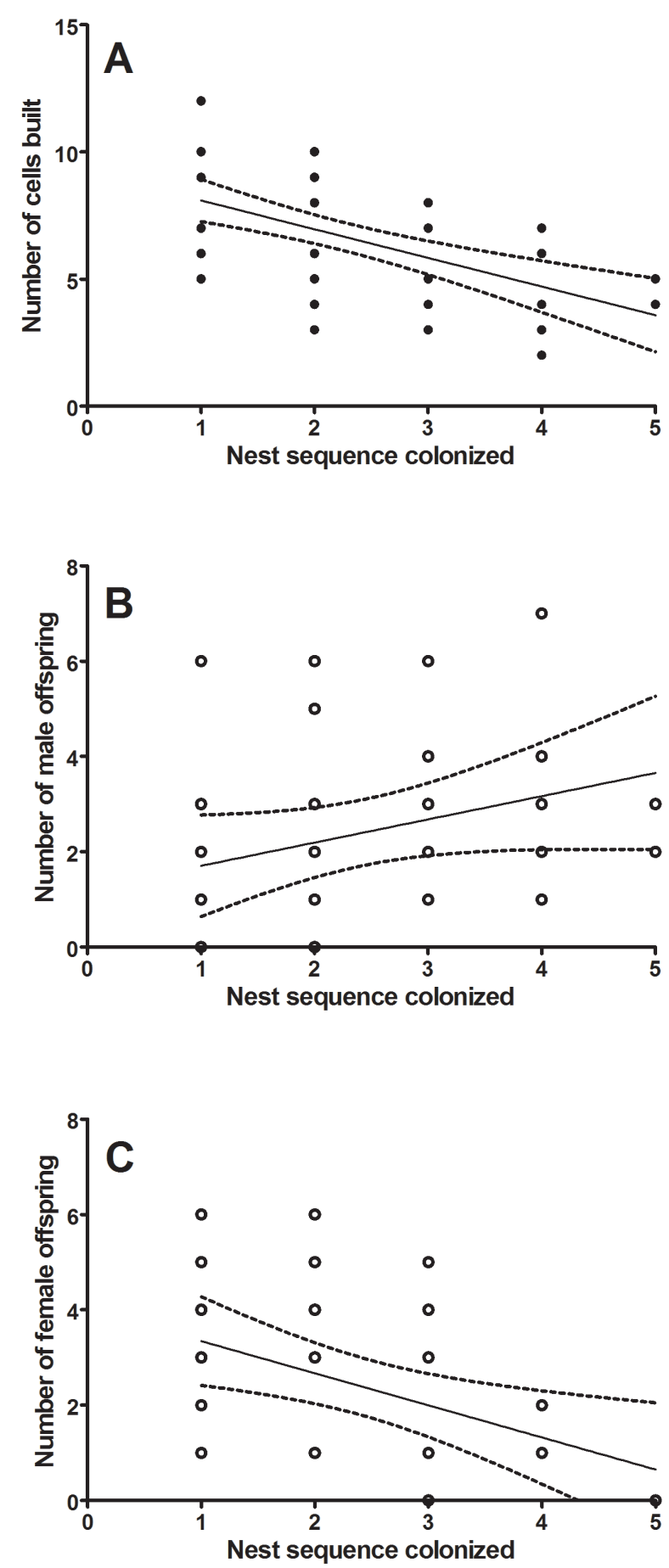

Fig. 2.

Relationship between the sequence of nest colonized by the $O$. rufa female, and the number of cells constructed in each nesting tube (A), the number of males (imago stage) produced (B) and the number of females (imago stage) produced (C). Regression lines in each case are represented with $95 \%$ confidence intervals (depicted with dotted lines). The data for variables are from 9 individual females fewer cells $(\bar{x}=7.6 \pm 2.07)$ compared to females colonizing 2 or more nest tubes. The most cells were built when a single female occupied 5 nest tubes $(\bar{x}=31 \pm 4.24)$. The data passed a normality test (KS 0.2050, $p>0.10$ ) and a regression analysis revealed that there was a significant positive linear relationship $(R$ square $=0.82$ with no significant departure from linearity $p=0.06$ ) between the number of nests colonized to the number of cells built (correlation coefficient $0.90 \mathrm{Fig}$. $1 \mathrm{~A}$ inset). One-way ANOVA with the Tukey-Kramer post-hoc test showed that the average number of cells built depended on the number of nests occupied, and was statistically significant $(F(4,24)-40.54$, $p<0.001$, Fig. 1A). However, no significant differences were observed in the number of cells built when 2 or 3 nest tubes were colonized or when 4 or 5 nest tubes were colonized (Fig. 1A).

The data related to the number of offspring, and offspring's relationship to the number of nests colonized also passed the normality test (KS $0.2283, p>0.10)$. Regression analysis revealed a significant positive linear relationship ( $R$ square $=0.77$ with no significant departure from linearity $p=0.08$ ) between the two variables (correlation coefficient 0.87, Fig. 1B inset). Also, the average number of offspring (progeny) developed, was statistically significant with the number of nests colonized $(F(4,24)-28.60$, $p<0.001$, Fig. 1B). However, no significant difference was observed in offspring number between 2 and 3 nests colonized, 3 and 4 nests colonized, or between 4 and 5 nests colonized (one-way ANOVA, Tukey-Kramer post-hoc test) (Fig. 1B). Thus, the number of cells constructed as well as the number of offspring, increased with the number of built nests.

Effect of sequence of colonized nests on number of cells generated and on the sex and number of offspring

A significant negative relationship was found between the sequence of occupied nests and the number of cells built per individual female (correlation coefficient - $0.54 ; p<0.0001$, Fig. 2A). In females colonizing up to five nests, females built an average of eight cells in the first nest 
and the number declined to five in the fifth nest. A weak relationship was observed between nest sequence occupied by a single female and the number of male offspring generated (correlation coefficient $0.30, p=0.08$, Fig. 2B). But, a power analysis revealed the power of the test as 1.0, so it is likely that a relationship exists between sequence of nests colonized by a female and the number of male progeny generated. The nest sequence, however, showed a negative relationship with number of developed females (correlation coefficient -0.45; $p=0.009$, Fig. 2C). Thus, the number of cells generated by the sequence of nests occupied as well as the number of female progeny generated, showed a similar trend, while in the case of males - it was the opposite.

\section{Effect of nest sequence on offspring sex ratio}

Sex ratio is represented as the proportion of males to the total number of adult bees (both males and females). The lowest proportion of males was produced by females with only one nest, whereas the highest proportion of males was produced by females with five nests. The proportion of males was not significantly different between nest tubes 1 and $2(0.3 \pm$ $0.1)$, but it was significantly lower $(p=0.005)$ than nest tubes 3 and $4(0.7 \pm 0.08)$ which did not differ between themselves (Fig.3). The proportion of males increased in the sequence and number of colonized nests. A higher proportion of males developed in nesting tubes 3 and 4. Moreover, we did not detect any females in fifth nest tube in all of the examined nests (Fig. 3). Thus, we observed a higher proportion of females in nest tubes 1 and $2(0.7 \pm 0.1)$. The female proportion declined sharply to $0.3 \pm 0.06$ in nest tubes 3 and 4.

\section{Offspring reduction}

A number of factors caused a reduction in offspring abundance in 0 . rufa females as depicted in Fig. 4A, B, C, D. Adults did not develop in $32.2 \%$ of all analysed cells due to various reasons, or the cells were not provisioned with pollen and/or egg. The percentage of empty cells increased with the sequence of nest tubes colonized (Fig. 4A). The highest mortality was observed before imaginal moult, in developmental stages (13.9\% of all analysed cells) manifested by the presence of dead eggs, larvae, prepupe and pupae (Fig. 4B). Develop-

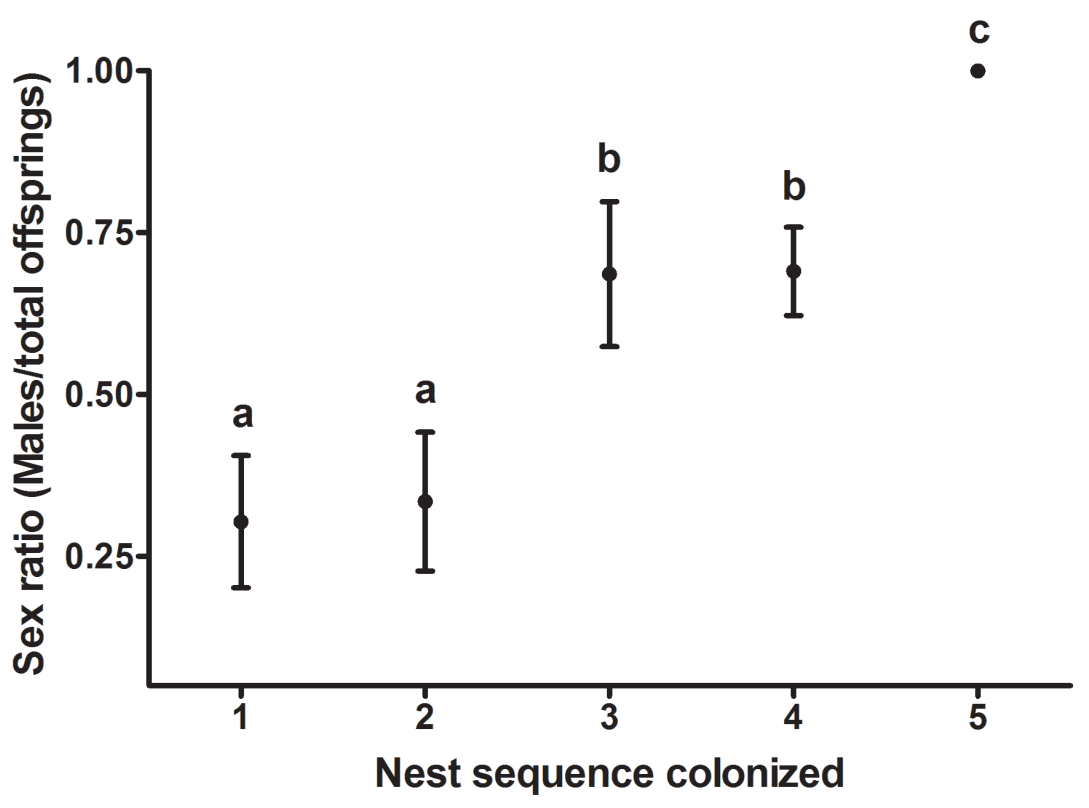

Fig. 3.

Male offspring ratio depending on the sequence of nests colonized by the 0 . rufa female. Male ratio was calculated as the freshly emerged male offspring out of the total number of offspring emerged. Symbols represent the mean male ratio. Bars represent the SD of the means. Symbols with different superscripts are significantly different at $p<0.05$ 

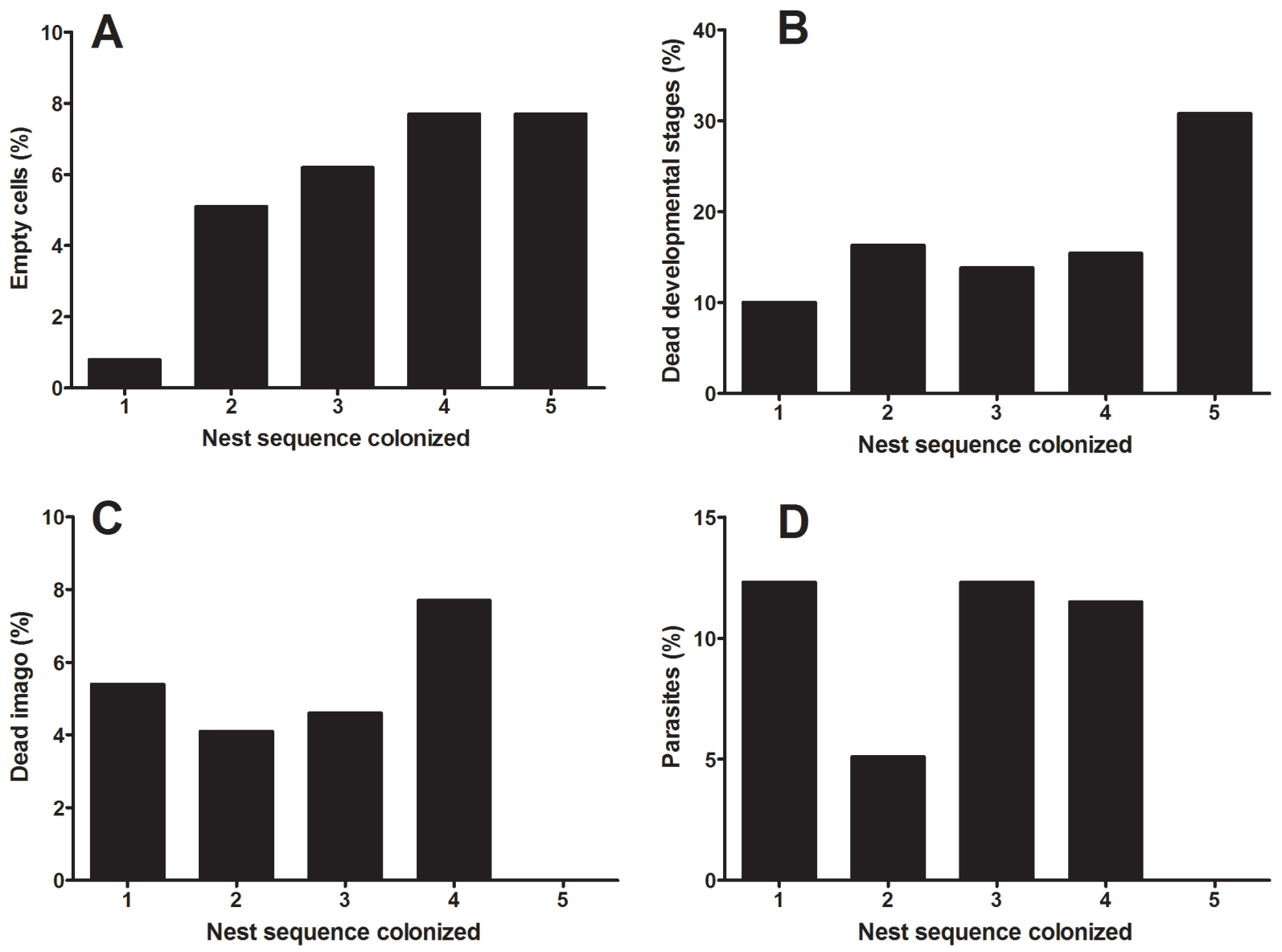

Fig. 4.

Percentage reduction in offspring in the sequence of nests colonized by 0 . rufa females. All data were calculated as the percentage of observations based on total number of tested cells in particular nests. A - empty cells (an average number of cells without any stages in particular nest); B - dead developmental stages (before imaginal moult: eggs, larvae, pupa); C - dead imagos (after imaginal moult); $\mathbf{D}$ - parasites inside the cells

mental mortality was the most frequent in the fifth nest tube colonized. The percentage of dead imago was highest in the fourth nest tube and no dead imago were observed in the fifth nest tube (Fig. 4C). The second most important factor contributing to offspring reduction was parasite activity (9.6\% of all analysed cells) (Fig. 4D). The main parasites we found in the nests of the red mason bee were Sapyga quinquepunctata (Hymenoptera: Sapygidae) - parasite of pollen provision, Monodontomerus obscurus (Hymenoptera: Torymidae) and Hemipenthes morio (Diptera; Bombyliidae) - parasites that develop in the cocoon of the red mason bee.

\section{DISCUSSION}

In general, the time needed by bees to build a nest, and thus build their reproductive success, is limited by the following factors: nesting location, food supply for the offspring, and the number of oocytes produced by the female (Rosenheim et al., 1996). Food limitation can reduce reproductive success of 0 . pumila directly, as well as indirectly. If there is a food scarcity the susceptibility to parasitism increases (Goodell, 2003). The amount of time to provision a cell is determined by transport capacity and trips required per cell. The highest provisioning rates are achieved by bees carrying very large pollen loads at intermediate trip duration (Neff, 2008). The reproductive success of a single O. rufa female depends on the number of cells constructed, the ability to provision the cells with pollen, and depositing of one egg on the provision during its lifespan. The maximum number of eggs laid by an individual bee is limited by the biological capabilities of O.rufa, whose ovaries contain a total of 42 oocytes (Thalmann, 1991). However, the actual number 
of laid eggs is always lower than the number of oocytes. The average maximum number of eggs oviposited per Osmia spp. female was found to be 31 in 0 . excavata, 23 in 0 . cornifrons, 25 in 0 . imaii, and 14 in 0 . taurus (Maeta, 1978), with the ability to build up to 30 cells in several tubes (Torchio, 1989; Neff \& Simpson, 1992; Vicens et al., 1993; Bosch, 1994). In our experiment, 0 . rufa females built, on average, 16 cells and produced 14 eggs. Some females built over 30 cells (maximum of 34) using 4-5 nesting tubes. Nearly a quarter of the observed females (24.1\%) occupied four or five tubes and built 28-34 cells, which reflected the maximum reproductive potential of the females. Interestingly, we observed that the total number of cells constructed was positively correlated with the number of nests colonized, as also was the number of offspring increased with number of nests colonized. However, the number of cells constructed per nest tube declined with the sequence of nest tubes colonized by a single female.

According to previous work by Torchio (1985), the number of cells built by 0 . lignaria females depends on the weather conditions and food source. In the favourable, artificial greenhouse environment, females of this species settled six tubes and built 38 cells. The highest number of cells in one tube was 14 (Torchio, 1989). Osmia lignaria propinqua females build the highest number of nest cells per one nesting tube at the beginning of the nesting period and the lowest number at the end of that time (Torchio \& Tepedino, 1980). Similarly, O. cornuta females build the highest number of cells in the first half of the nesting period (Bosh \& Vicens, 2005). Thus, the number of cells in a nest decreases gradually with the age of the female. This corresponds with the data obtained from our study where we found that the number of cells declined with the sequence of nest tubes colonized by an individual $\boldsymbol{O}$. rufa female. The number of female offspring generated also declined with the sequence of occupied nests, but there was a tendency for an increase in the number of male offspring along with an increase in sequence of occupied nests. On the other hand, the number of male offspring per one nest of 0 . cornifrons increases simultaneously (Sugiura \& Maeta, 1989). The proportion of male offspring in the nest in the late nesting period also increases in other Osmia species (Tepedino \& Torchio, 1982; Bosh \& Vicens, 2005).

Individual analysis of the nests of 0 . rufa females indicated that in consecutive nests, only the number of females decrease, whereas the number of males remains at the same level thus increasing the proportion of males. The number of cells with females declines as a function of sequence of colonized nests starting from one to five. The largest differences in the number of cells and female offspring per one nest are between the first two nests and the ones that followed. These results are similar for other Osmia spp. (Torchio \& Tepedino, 1980; Bosh \& Vicens, 2005). This information enables us to divide the nesting period of $O$. rufa into two parts and we can then distinguish periods of higher and lower female nesting activity as well as predict the proportion of each sex in subsequent nests which are colonized.

In general, females may use the maximum of their reproductive capabilities only in optimum environmental conditions. Apart from ecological conditions, female weight and vitality have an effect on fecundity which is shown as the number of built nest (Kim, 1997; Ivanov, 2006). It is also important to take into consideration death caused by parasites, ontogenesis disorders, and imago death during the wintering period. All these factors have an impact on the reproductive success of a bee.

In our study, the reasons for offspring reduction were catalogued and attributed to: empty cells, death during the developmental stages, death during imago, and to parasitism. All of these factors resulted in a substantial reduction in the number of offspring produced. The Osmia cornuta aggregation showed an average mortality rate of $15 \%$. The mortality rate was mainly caused by developmental disorders (12\%) and presence of parasites (about 3\%) (Bosh \& Vicens, 2005). Monodontomerus obscurus and Hemipenthes morio occurring in Northern and Western Europe respectively, are parasitoids that can often 
be found in the nests of solitary bees. Sapyga quinquepunctata are classified as cleptoparasites because their larvae feed upon the pollen provisions in cells (Krunić et al., 2005). All these parasites were also recorded in this study. It has been suggested that during the season, when food supplies slowly decrease, the risk of parasites can be diminished by accumulating lower amounts of pollen provision and producing a higher number of males (Seidelmann, 2006). Taken together, our study provides comprehensive information concerning the individual reproductive potential of $O$. rufa females. This information can contribute to a better understanding of the population ecology of this particular species. Moreover, our findings can improve the rearing and management of this bee species as a crop pollinator. Our results can also contribute to a better assessment of the number of artificial nests in accordance with the number of nesting females and also can serve as a starting point to develop a method to control the sex ratio of the next generation.

In conclusion, Osmia rufa females are able to occupy from one to five nests during the nesting season. These females build cells ranging from seven to thirty-four cells altogether. An individual bee can reach maximum reproductive potential (including number of cells built and eggs oviposited) when it occupies at least four nests. The number of cells and sex ratio in a nest is related to the sequence of nest tubes colonized by an individual female. The highest number of cells and female offspring are located in the first two occupied nests.

\section{REFERENCES}

Batra, S.W. (1978). Aggression, territoriality, mating and nest aggregation of some solitary bees (Hymenoptera: Halictidae, Megachilidae, Colletidae, Anthophoridae). Journal of Kansas Entomological Society, 57(4), 547-559.

Bosch, J. (1994). The nesting behavior of the mason bee Osmia cornuta L. with special reference to its pollinating potential (Hymenoptera, Megachilidae). Apidologie, 25, 84-93.
Bosch, J., \& Kemp, W.P. (2000). Development and emergence of the orchard pollinator Osmia lignaria (Hymenoptera: Megachilidae). Environmental Entomology, 29, 8-13.

Bosch, J., \& Kemp, W.P. (2004). Effect of pre-wintering and wintering temperature regimes on weight loss, survival, and emergence time in the mason bee Osmia cornuta (Hymenoptera: Megachilidae). Apidologie, 35, 469-479.

Bosch, J., \& Vicens, N. (2005). Sex allocation in the solitary bee Osmia cornuta. do females behave in agreement with Fisher's theory? Behavioral Ecology and Sociobiolgy, 59, 124-132.

Cane, J. H., Griswold, T., \& Parker, F. D. (2007). Substrates and materials used for nesting by North American Osmia bees (Hymenoptera: Apiformes: Megachilidae). Annals of the Entomological Society of America 100(3), 350-358.

Fliszkiewicz, M., Giejdasz, K., \& Wilkaniec, Z. (201 1). The importance of male red mason bee (Osmia rufa L.) and male bufftailed bumblebee (Bombus terrestris L.) pollination in blackcurrant (Ribes nigrum L.). Journal of Horticultural Science and Biotechnology, $86,457-460$.

Goodell, K. (2003). Food availability affects Osmia pumila (Hymenoptera: Megachilidae) foraging, reproduction, and brood parasitism. Oecologia, 134, 518-527.

Ivanov, S. P. (2006). The nesting of Osmia rufa (L.) (Hymenoptera, Megachilidae) in the Crimea: Structure and composition of nests. Entomological Review, 86(5), 524-533.

Jauker, F., Bondarenko, B., Becker, H. C., \& SteffanDewenter, I. (2012). Pollination efficiency of wild bees and hoverflies provided to oilseed rape. Agricultural and Forest Entomology, 14(1), 81-87.

Kaminski, P. (2010). Gametoclonal and Somaclonal Variation among Head Cabbage Androgenic Lines of R1 and R2 Generations Obtained from Jaguar F1 Hybrid. Journal Agricultural Science, 2(2), 119. 


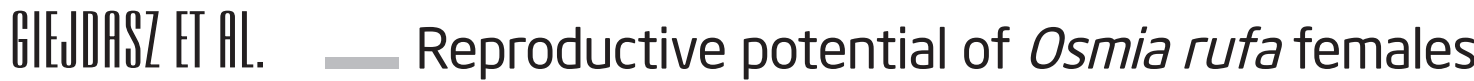

Kim, J. Y. (1 997). Female size and fitness in the leafcutter bee Megachile apicalis. Ecological Entomology, 22(3), 275-282.

Krombein, K.V. (1967). Trap-Nesting Wasps and Bees: Life Histories, Nests, and Associates. Smithsonian Press, Washington DC.

Krunic, M., Pinzauti, M., Felicioli, A., \& Stanisavljevic, L. J. (1995). Further observations on Osmia cornuta Latr. and Osmia rufa L. as alternative fruit pollinators, domestication and utilization. Archives of Biological Sciences Belgrade, 47(1-2), 59-66.

Krunic, M., Stanisavljevic, L., Pinzauti, M., \& Felicioli, A. (2005). The accompanying fauna of Osmia cornuta and Osmia rufa and effective measures of protection. Bulletin Insectology, 58, 141-152.

Neff, J. (2008). Components of nest provisioning behavior in solitary bees (Hymenoptera: Apoidea). Apidologie, 39(1), 30-45.

Neff, J., \& Simpson, B. (1992). Nest biology of Osmia (Diceratosmia) subfasciata Cresson in central Texas (Hymenoptera: Megachilidae). Pan-Pacyfic Entomology, 68, 15-26.

Maeta, Y. (1978). Comparative Studies on the Biology of the Bees of the Genus Osmia of Japan, with Special Reference to Their Managements for Pollinations of Crops (Hymenoptera: Megachilidae). Bulletin of Tohoku National Agricultural Experiment Station, 57: 1-221.

Raw, A. (1972). The biology of the solitary bee Osmia rufa(L.) (Megachilidae) Transaction of Royal Entomological Society of London 124, 213-229.

Rogers, S. R., Tarpy, D. R., \& Burrack, H. J. (2013). Multiple criteria for evaluating pollinator performance in highbush blueberry (Ericales: Ericaceae) agroecosystems. Environmental entomology, 42(6), 1201 1209.

Rosenheim, J.A. (1990). Density-dependent parasitism and the evolution of nesting aggregations in the solitary Hymenoptera. Annals of the Entomological Society of America, 83, 277-286.

Rosenheim, J.A., Nonacs, P., \& Mangel, M. (1996). Sex ratios and multifaceted parental investment. American Naturalist, 148, 501-535.

Sedivy, C., \& Dorn, S. (2014). Towards a sustainable management of bees of the subgenus Osmia (Megachilidae; Osmia) as fruit tree pollinators. Apidologie, 45, 88- 105.

Schittenhelm, S., Giadis, T., \& Rao, V.R. (1997). Efficiency of various insects in germplasm regeneration of carrot, onion and turnip rape accessions. Plant Breeding, 176, 369-375.

Seidelmann, K. (1999). The function of the vestibulum in nest of a solitary stem-nesting bee, Osmia rufa L. Apidologie, 30, 19-29.

Seidelmann, K. (2006). Open-cell parasitism shapes maternal investment patterns in the Red Mason bee Osmia rufa. Behavioral Ecology, 7 7, 839-848.

Sugiura, N., \& Maeta, Y. (1 989). Parental investment and offspring sex ratio in a solitary mason bee, Osmia cornifrons (Radoszkowski) (Hymenoptera: Megachilidae). Japanese Journal of Entomology, 57,861875.

Szentgyörgyi, H., \& Woyciechowski, M. (2013). Cocoon orientation in the nests of red mason bees (Osmia bicornis) is affected by cocoon size and available space. Apidologie, 44, 334-341.

Thalmann, U. (1991). Ausgewählte untersuchungen zur reproduktionsbiologie der solitär-bienen-arten Anthophora acervorum (Linné, 1758) und Osmia rufa (Linné, 1758). Dissertation (A), MLU Halle.

Tasei, J.N. (1973). Observation sur le development d'Osmia cornuta Latr. et Osmia rufa L. (Hymenoptera: Megachilidae). Apidologie, 4, 295-315.

Tepedino, V. J., \& Torchio, P.E (1 982). Temporal variability in the sex ratio of non-social bee, Osmia lignaria propinqua extrinsic determination or the tracking 


\section{J. APIC. SOLI. VOL. G0 NO. 12016}

of an optimum. Oikos, 38, 177-182.

Torchio, P.F. (1985). Field experiments with the pollinator species, Osmia lignaria propinqua Cresson, in apple orchards: V (1979-1980), methods of introducing bees, nesting success, seed counts, fruit, yields. (Hymenoptera: Megachilidae). Journal of Kansas Entomological Society, 58, 448-464.

Torchio, P.F., \& Tepedino, V.J. (1980). Sex ratio, body size and seasonality in solitary bee, Osmia lignaria propinqua Cresson (Hymenoptera: Megachilidae). Evolution, 34, 993-1003.

Torchio, P.F. (1989). In-nest biologies and development of immature stages of three Osmia species (Hymenoptera: Megachilidae). Annals of the Entomological Society of America, 82, 599-615.

Ulbrich, K., \& Seidelmann, K. (2001). Modeling population dynamics of solitary bees in relation to habitat quality. Web Ecology, 2(1), 57-64.

Vicens, N., Bosh, J., \& Blas, M. (1993). Analysis of the nests of some Osmia species nesting in pre-established cavities. Orsis, 8, 41-52.

Wilkaniec, Z., Giejdasz, K., \& Fliszkiewicz, M. (2000). Effect of differentiated nest tubes on theirr settlement by the solitary bee Osmia rufa L. (Megachilidae). (in Polish). Pszczelnicze Zeszyty Naukowe, 44, 119-126.
Wilkaniec, Z., \& Radajewska, B. (1996). Solitary bee Osmia rufa L.(Apoidea, Megachilidae) as pollinator of strawberry cultivated in an unheated plastic tunnel. In III International Strawberry Symposium, 439, 489-494.

Wójtowski, F., Wilkaniec, Z., \& Szymaś, B. (1995). Increasing the total number of Osmia rufa L. (Megachilidae) in selected biotopes by controlled introduction method. [in] Changes in Fauna of Wild Bees of Europe. (ed. Banaszak J.) Pedagogical Univ. BydgoSZCZ.

Wójtowski, F., \& Wilkaniec, Z. (1978). Rearing and utilization of solitary bees settled in nest traps (in Polish). Instrukcja Wdrożeniowa AR Poznań 1-10. 
